\title{
SOYBEAN BIOESTER OBTAINED IN A BUBBLE COLUMN ESTERIFICATION REACTOR - A RHEOLOGICAL STUDY
}

\author{
SORINA BORAN ${ }^{\mathrm{a}}$, ANDRA TĂMĂȘ ${ }^{\mathrm{a}^{*}}$, GIANNIN MOȘOARCĂ ${ }^{\mathrm{a}}$
}

\begin{abstract}
The paper presents the rheological characterization of a bio-ester with possible lubricant properties, obtained from soybean oil fatty acids. The rheological characterization was carried out under thermostatic conditions, using a Brookfield CAP2000+L viscometer in the characteristic domain of these fluids. The variation of the apparent viscosity $\eta_{a}$ as a function of shear rate $\dot{\gamma}$ and the variation of the two indices ( $\mathrm{K}$ and $\mathrm{n}$ ) as a function of temperature were determined, as well as the flow activation energy, $E_{a}$ from Arrhenius type equations. A rheological model was proposed.
\end{abstract}

Keywords: apparent viscosity, fatty acids, non-Newtonian behavior

\section{INTRODUCTION}

At present time, environmental protection as well as concerns regarding future energetic security have become of prime importance. That is why the use of bio-based lubricants is important in the transport and industrial sectors, to the detriment of classic synthetic lubricants.

With proper formulation of the base oil and with proper use of additive packages, bio-based lubricants can work better than conventional lubricants [1].

It is important to study the rheological properties of lubricating products, with or without additions of various additives, in order to know their tribological behavior [2-8].

Environmental protection is at present a very important issue [9]. That is why eco-friendly technologies are to be used for protecting the environment. Esterification processes can be performed in bubble column reactors, which were also used in different technologies, such as polymerization processes, when the residual monomer did not appear in the final product [10-14] and the heat transfer may be monitored by the boiling heat transfer coefficients [15-18].

\footnotetext{
a Politehnica University Timișoara, Faculty of Industrial Chemistry and Environmental Engineering, 6 Vasile Pârvan Bd., RO-300223, Timișoara, Romania

*Corresponding author: andra.tamas@upt.ro
} 
As a continuation of research undertaken in previous years [19-24], at present we aim to obtain lubricating products that do not affect the environment, but which have superior lubricating properties, using bubble column reactors technologies.

For this purpose, it was obtaining a bio-ester with possible lubricating properties using as acid component the soybean oil fatty acids, $n$ propanol and $p$-toluene-sulphonic acid as catalyst, in a bubble column reactor. The rheological behavior of the bio-ester was studied.

\section{RESULTS AND DISCUSSION} Table 1.

Some physico-chemical properties of the bio-ester are presented in

Table 1. Some physico-chemical properties of the bio-ester

\begin{tabular}{|l|c|}
\hline \multicolumn{1}{|c|}{ Property } & Value \\
\hline Appearance & viscous, opalescent \\
\hline Color & orange \\
\hline Acidity index, $\mathrm{mg} \mathrm{KOH} \mathrm{g}^{-1}$ & $<1$ \\
\hline Refractive index, $\left(20^{\circ} \mathrm{C}\right)$ & 1.4562 \\
\hline Density $\left(25^{\circ} \mathrm{C}\right), \mathrm{g} \mathrm{cm}^{-3}$ & 0.9981 \\
\hline
\end{tabular}

The variation of the apparent viscosity $\eta_{a}$ as a function of shear rate $\dot{\gamma}$, at different temperature values, is shown in Figure 1 .

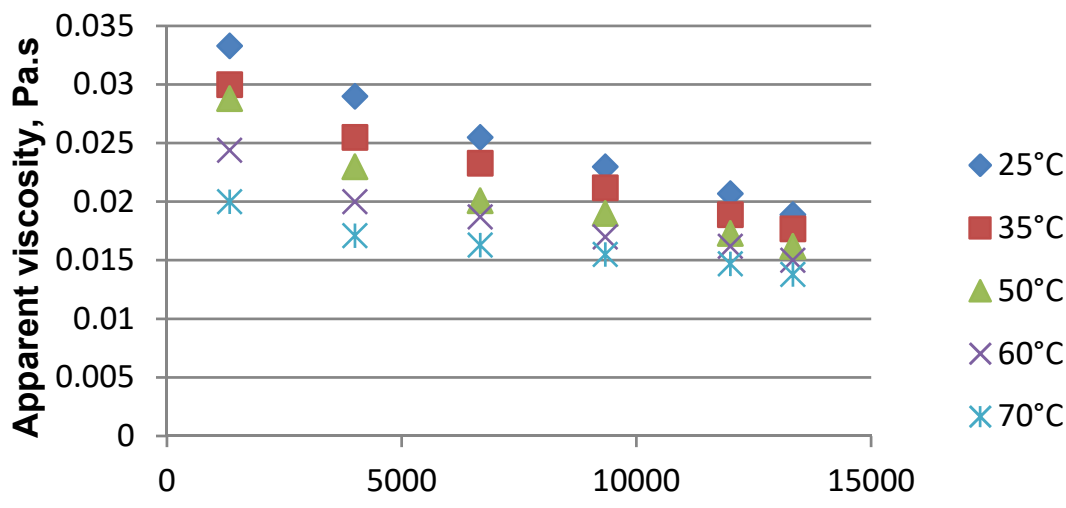

Shear rate, $1 / \mathrm{s}$

Figure 1. Apparent viscosity vs. shear rate for bio-ester at different temperature values 
It is noticed that the values of the apparent viscosity decrease with the shear rate increasing, behavior that is characteristic of non-Newtonian fluids (shear-thinning behavior). The dependence $\eta_{a}=f(\dot{\gamma})$ can be described by the equation Ostwald de Waele, equation (1):

$$
\eta_{a}=K \cdot \dot{\gamma}^{n-1}
$$

where: $\mathrm{K}$ - the flow consistency index, $\mathrm{Pa} \cdot s^{n} ; \mathrm{n}$ - the flow behavior index $[25,26]$.

The particular forms of equation (1), corresponding to the five temperature values, are shown in Table 2.

Table 2. Particular forms of equation (1)

\begin{tabular}{|c|c|c|}
\hline Temperature, ${ }^{\circ} \mathbf{C}$ & $\eta_{a}=f(\dot{\gamma})$ & $\mathbf{R}^{\mathbf{2}}$ \\
\hline 25 & $\eta_{a}=0.19 \cdot \dot{\gamma}^{-0.234}$ & 0.9191 \\
\hline 35 & $\eta_{a}=0.15 \cdot \dot{\gamma}^{-0.219}$ & 0.9343 \\
\hline 50 & $\eta_{a}=0.164 \cdot \dot{\gamma}^{-0.24}$ & 0.9836 \\
\hline 60 & $\eta_{a}=0.103 \cdot \dot{\gamma}^{-0.198}$ & 0.9740 \\
\hline 70 & $\eta_{a}=0.058 \cdot \dot{\gamma}^{-0.147}$ & 0.9658 \\
\hline
\end{tabular}

The pseudoplastic behavior is also demonstrated by the sub-unit values of the flow behavior index.

The variation of the two indices $(K, n)$ as a function of temperature is shown in Figure 2, and in Figure 3 is presented the variation of the apparent viscosity with temperature, for three values of the shear rate.

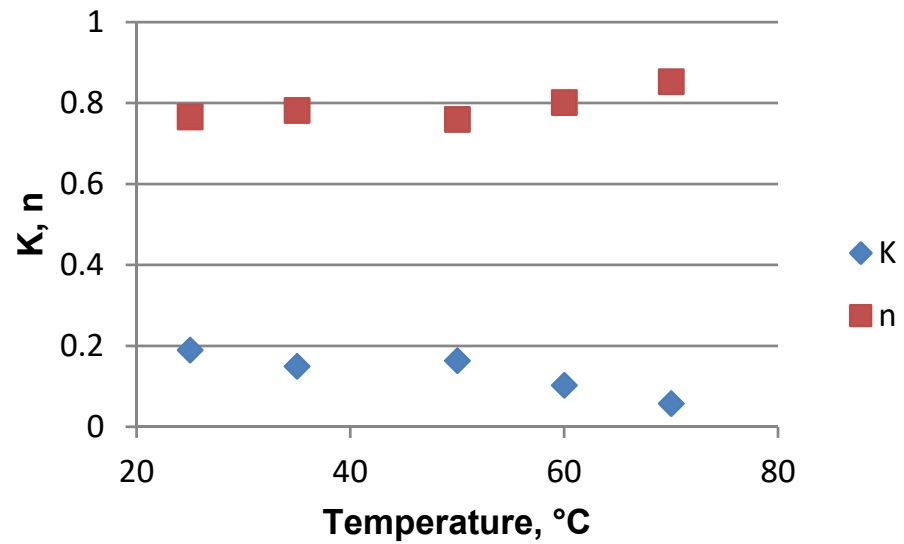

Figure 2. The material consistency and flow behavior index vs. temperature 


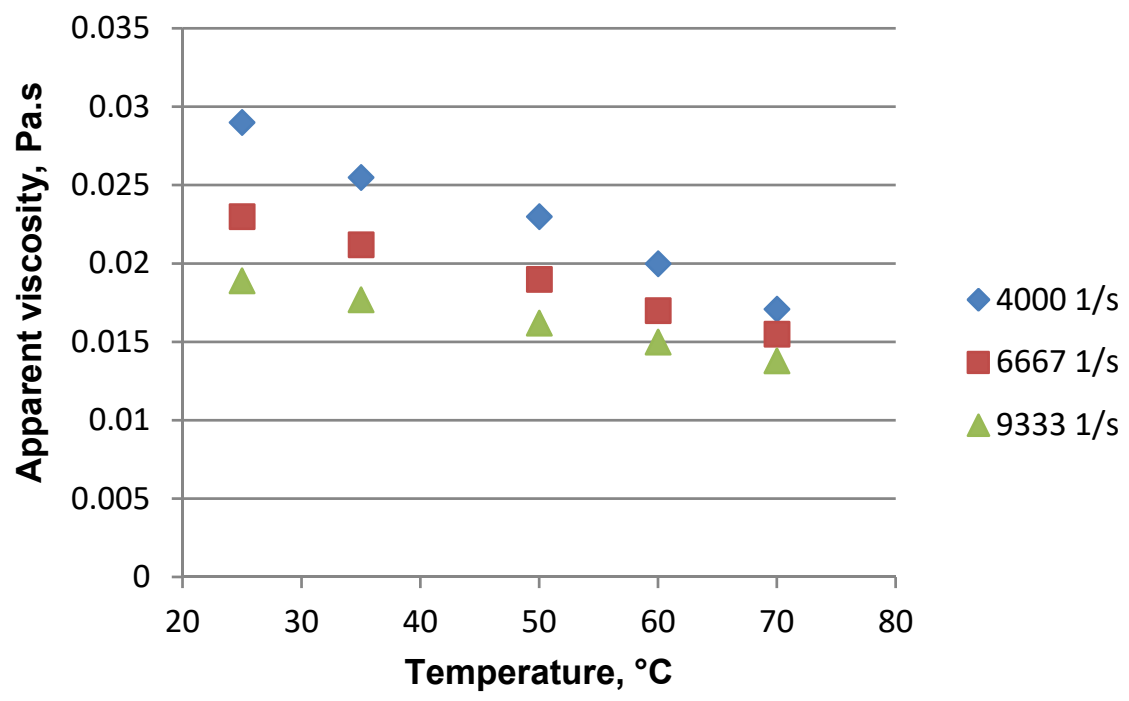

Figure 3. Apparent viscosity vs. temperature at different shear rate values

The temperature increase leads to microdrops mobility intensification which influences the activation energy of the system. The phenomenon can be explained by an Arrhenius type equation (equation (2)):

$$
\eta_{a}=A^{\prime} \cdot e^{\frac{E_{a}}{R \cdot T}}
$$

where $E_{a}$ is the activation energy of viscous flow, $\mathrm{J} \mathrm{mol}^{-1} ; R$ is the gas general constant, $\mathrm{J} \mathrm{mol}^{-1} \mathrm{~K}^{-1} ; T$ is absolute temperature and $A^{\prime}$ represents the material constant, $\mathrm{Pa}$ s. The dependence $\operatorname{In} \eta_{a}=f(1 / T)$ was graphically represented, as obtained from the logarithmic form of equation (2), for apparent viscosity values corresponding to the three chosen values of the shear rate. Particular expressions of equation (2) as well as the values of the activation energy are presented in Table 3.

Table 3. Particular forms of equation (2)

\begin{tabular}{|c|c|c|}
\hline$\dot{\gamma}, \mathbf{s}^{-1}$ & $\eta_{a}=A^{\prime} \times 10^{4} \cdot \exp \left(E_{a} / R \cdot T\right.$ & $\mathbf{E}_{\mathbf{a}, ~} \mathrm{~kJ} \cdot \mathrm{mol}^{-1}$ \\
\hline 4000 & $\eta_{a}=6.6 \cdot \exp (1130.7 / T)$ & 9.4 \\
\hline 9333 & $\eta_{a}=11.9 \cdot \exp (886.2 / T)$ & 7.4 \\
\hline 13333 & $\eta_{a}=18.4 \cdot \exp (696.6 / T)$ & 5.8 \\
\hline
\end{tabular}




\section{CONCLUSIONS}

It was studied the rheological behavior of a bio-ester obtained from soybean oil fatty acids in the bubble column reactor at reflux.

The synthesized ester exhibits pseudoplastic behavior characterized by the decrease in apparent viscosity with the shear rate increasing and subunit values of the flow behavior index. These values increase with increasing temperature, without exceeding the value 1 .

It is also observed that the activation energy of viscous flow decreases with the shear rate increasing.

\section{EXPERIMENTAL SECTION}

General procedure for ester preparation

Synthesis of the bio-ester was performed in the bubble column reactor at reflux. The ratio fatty acids from soybean oil: $n$-propanol was 1:2, using $0.4 \%$ catalyst [17-22].

The physico-chemical properties were determined by using standardized techniques: the pycnometer method for density determination and the Abbe refractometer for refractive indices.

The rheological characterization of the samples was carried out under thermostatic conditions (temperature range $25 \div 70^{\circ} \mathrm{C}$ ), using a Brookfield $C A P 2000+L$ viscometer in the characteristic domain of these fluids.

\section{REFERENCES}

1. A.Z. Syahir et. al.; J. Cleaner Prod., 2017, 168, 997-1016

2. C.C. Chou; S.H. Lee; J. Mater. Process. Technol., 2008, 201, 542-547

3. J.E. Martín-Alfonso; C. Valencia; Tribol. Int., 2015, 90, 426-434

4. M.H. Esfe; H. Rostamian; M. Rejvani; M.R.S. Emami; Physica E, 2018, 102, 160-170

5. M.H. Esfe; M. Afrand; W-M. Yan et. al.; Int. Commun. Heat Mass Transfer, 2016, 76, $133-138$

6. T. Sui; M. Ding; C. Ji et. al.; Ceram. Int., 2018, 44, 18438-18443

7. A.A. Nadooshan; M.H. Esfe; M. Afrand; Physica E, 2017, 92, 47-54

8. M.J. Souza de Carvalho; P.R. Seidl; C.R.P. Belchior; J.R. Sodre; Tribol. Int., 2010, 43(12), 2298-2302

9. G. Mosoarca; C. Vancea; S. Popa; S. Boran; Bull. Environ. Contam. Toxicol., 2018, 100(5), 733-739 
10. S. Popa; C. Csunderlik; S. Florea; V. Jâșcanu; D. Jurcău, N. Pleșu; Rev. Chim., 2002, 53(4), 259-263

11. S. Popa; V. Jâșcanu; D. Jurcău, N. Pleșu; Rev.Chim., 2003, 54(7), 595-598

12. S. Popa; C. Csunderlik; V. Jâșcanu; D. Jurcău, N. Pleșu; Materiale plastice, 2003, 40(4), 177-181

13. S. Popa; C. Csunderlik; V. Jâșcanu; D. Jurcău, N. Pleșu; Materiale plastice, 2004, 41(2), 62-65

14. S. Popa; S. Boran; Materiale plastice, 2016, 53(3), 410-413

15. A. Tămaş; S. Boran; Studia UBB Chemia, 2019, LXIV, 1, 93-102

16. S. Boran; S. Nițu; Materiale Plastice, 2017, 54(2), 386-389

17. S. Popa; S. Boran; V. Simulescu; Materiale Plastice, 2017, 54(2), 359-361

18. S. Boran; A. Tămaş; Materiale Plastice, 2016, 53(3), 505-508

19. S. Popa; S. Boran; Rev. Roum. Chim., 2016, 61(11-12), 851-855

20. S. Popa; S. Boran; Rev. Roum. Chim., 2015, 60(10), 991-995

21. S. Boran; A. Tămaş; J. Serb. Chem. Soc., 2014, 79 (2), 241-251

22. S. Boran; A. Tămaş; Studia UBB Chemia, 2013, LVIII, 1, 21-30

23. D. Kohn, S. Popa, Exp. Heat Transfer, 1999, 12(3), 193-202

24. S. Popa, S.Boran, Thermal Science, 2015, 21(5), 2031-2037

25. A. Miclăuș; V. Pode; Cazuri particulare de curgere a fluidelor ideale si reale. Elemente de reologie, Casa Cărții de Știință, Cluj-Napoca, 2018, pp. 49

26. A. Ya. Malkin; A.I. Isayev; Rheology: Concepts, Methods, and Applications, $2^{\text {nd }}$ ed., Chem Tec Publishing Toronto, 2012, pp. 131. 